\title{
Effect of Spacing between Stone Columns on the Behavior of Soft Soil
}

\author{
Zeena A. Al-Kazzaz ${ }^{1, a}$ and Moataz A. Al-Obaydi ${ }^{1, b^{*}}$ \\ ${ }^{1}$ Civil Engineering Department, College of Engineering, University of Mosul, Mosul, Iraq \\ azeena.kazzaz@uomosul.edu.iq, ${ }^{\text {bdralobaydi@uomosul.edu.iq }}$
}

\begin{abstract}
Soil improvement by stone columns is extensively used, especially for the soft ones. This is because of their efficiency and no environmental impact. Several factors affect its efficiency in improving the mechanical properties of the soil, and the most important of these factors are the spacing, length, and diameter of the stone columns. In this study, the finite element method was used to study the impact of the spacing between the stone columns on the amount of settlement and the bearing capacity of the soil. The study comprises three different spaces (s) that were taken in relation to the columns' diameter $(\mathrm{d})$, which are $(\mathrm{s} / \mathrm{d}=3,4$, and 5$)$. In addition, three types of the sectional shape of column involved circular, rectangular, and square sections with different lengths of $(\mathrm{L} / \mathrm{d}=2$, $4,6,8$, and 10). The results showed that the spacing between the stone columns is effective when the vertical load is greater than $30 \mathrm{kN} / \mathrm{m}^{2}$, and below this, there is no effect of the spacing. In general, the settlement decreases, and the bearing capacity increases with the decrease in the spacing between the stone columns. The spacing becomes a more pronounced effect with the longer length of the stone columns. All sections of the stone columns with a short length of $(\mathrm{L} / \mathrm{d}=2)$ showed the same settlement of $271 \mathrm{~mm}$ at a distance $(\mathrm{s} / \mathrm{d}=5)$, which decreases by $7.4,6.6$, and $8.9 \%$ at a distance $(\mathrm{s} / \mathrm{d}=3)$ for the circular, rectangular and square sections respectively. In the case of long columns $(\mathrm{L} / \mathrm{d}=10)$, the settlement at $(\mathrm{s} / \mathrm{d}=3)$ improves by about $27.5 \%$ which drop to about $18 \%$ at $(\mathrm{s} / \mathrm{d}=5)$. A slight improvement in the soil's bearing capacity is associated with decreases in the spacing between the stone columns. The improvements in the bearing of soil treated with short columns $(\mathrm{L} / \mathrm{d}=2)$ are 6.0 , 6.5 , and $4.7 \%$ for circular, rectangular, and square sections, respectively, when changing the distance from $(\mathrm{s} / \mathrm{d}=5)$ to $(\mathrm{s} / \mathrm{d}=3)$. Whereas they become greater when increasing the columns' length to $(\mathrm{L} / \mathrm{d}=10)$ to be $7.9,9.2$, and $6.4 \%$.
\end{abstract}

Keywords: Stone column; soft soil; settlement; bearing capacity; finite element method.

\section{Introduction}

Stone Columns method is an efficient, low-cost, and environmentally friendly technique used to enhance the properties of soft cohesive and non-cohesive soils. It provides additional support to structures with light and moderate loads, such as medium-rise buildings, storage tanks, embankments, and many others. Several variables affect the attitude of the stone columns, including the diameter of the columns, their length, the space between the columns, and the type of stone column material. Many investigators mentioned that the spacing between the stone columns had a considerable effect on the behavior of the soil [1-3]. Woo et al. [4] stated that the spacing and diameter of the stone column have a pronounced effect on soil performance under the structures, while the length exhibited a lower impact. From the results of the laboratory tests on a rigid footing underneath by a soft soil treated with floating stone columns, Black et al. [5] concluded that the maximum settlement takes place at an area replacement ratio of 30\%. Maheshwari and Khatri [6] indicated a decrease in the deflection of foundation resting on the stone columns with decreased spacing between the columns, and the optimum (s/d) was between 3 to 3.5. El-Garhy et al. [7] found experimentally improving the settlement and bearing capacity functional to the area replacement ratio of the soft soil treated with floating granular stone columns. Eid et al. [8] analyzed a 3D model using the Abaqus program and found that when the number of stone columns increased from 1 to 9 , the load-bearing capacity enhanced by 1.6 for the encased stone columns and 1.3 for the ordinary columns.

Fattah et al. [9] supported embankment using stone columns with spacing to diameter ratios $(\mathrm{s} / \mathrm{d}=2.5,3$, and 4$)$. The settlement reduced by an average of 0.65 times that untreated soil, while the 
bearing capacity increased by amount range between 1.29 to 1.83 . As the spacing between columns decreased, the bearing capacity increased, and the optimum spacing was obtained at $2.5 \mathrm{~d}$. Later, Fattah et al. [10] carried out statistical analysis for their results as well as results from other works to predict the equation for bearing capacity of clay soil treated with floating stone columns. The predicted equation showed that the bearing capacity is mostly a function of the area replacement ratio. The bearing capacity of the stone columns group increased with decreased spacing between columns, i.e., increased the area replacement ratio. Mokhberi and Khademi [11] stated that the settlement decreased considerably in soil treated with 12 stone columns. Increasing the number of stone columns more than 12 had slightly affected the settlement.

Al-Waily et al. [12] examined the bearing capacity, settlement, and stress concentration of reinforced soil with stone columns. Both bearing capacity and stress concentration increased with the increasing number of columns. Bonab et al. [13] showed that the bearing capacity of the soft soil increased with increasing the diameter of stone columns and area replacement ratio. From their experimental results, Bouziane et al. [14] concluded that the spacing between stone columns arrangement in square or triangular scheme control the performance of the soil-stone columns system. The axial strain decreased and bearing capacity increased with decreasing spacing between columns. Nav et al. [15] used the finite element method to simulate the reinforced soil by stone columns. Results indicated that the settlement and bulging decreased with decreasing spacing between columns from $\mathrm{s} / \mathrm{d}=4$ to 2.5 . Thakur et al. [16] observed an increase in the carrying load capacity and reduction in soil settlement with the increasing number of stone columns. Previous studies focused on the variation of the spacing between the stone columns and its effect on the properties of the soil with columns of a circular section. Earlier work of Al-Obaydi and Al-Kazzaz [17] considered one spacing only between stone columns. In this work, the columns'spacing effect on some engineering properties of the soft soil was numerically studied using PLAXIS-2D code in the case of rectangular and square sections in addition to a circular section.

\section{Analysis Procedures}

Geological and Structural Elements. The characteristics of the numerical model were selected to investigate the effect of different variables on the soft clay soil in its natural state (untreated) and after treatment with stone columns. The characteristics of the geological formations used in the study are shown in Table 1. Also, it is involved the properties of the soil and the material of the stone columns used. The properties of the structural elements are also presented in Table 1, which includes the properties of a raft foundation with a thickness of $800 \mathrm{~mm}$. The nonlinear behavior of geological formations is represented by the Mohr-Coulomb criterion; whose behavior is Elastic Perfect-Plastic. At the same time, the structural elements are considered linear elements with linear-elastic behavior.

Table 1. Properties of the materials used in the analysis.

\begin{tabular}{|c|c|c|c|c|}
\hline \multirow{2}{*}{ Properties } & \multirow{2}{*}{ Units } & \multicolumn{3}{|c|}{ Materials } \\
\cline { 4 - 5 } & & Stone Column & Soft Soil & Raft Foundation \\
\cline { 3 - 5 } Model & & Mohr-Coulomb & Mohr-Coulomb & Linear-Isotropic \\
\hline$\gamma_{\text {unsat }}$ & $\mathrm{kN} / \mathrm{m}^{3}$ & 20 & 17 & 24 \\
\hline $\mathrm{E}$ & $\mathrm{kN} / \mathrm{m}^{2}$ & 50000 & 10000 & $30 \times 10^{6}$ \\
\hline$v$ & --- & 0.30 & 0.35 & 0.20 \\
\hline $\mathrm{c}$ & $\mathrm{kN} / \mathrm{m}^{2}$ & 0.20 & 10 & --- \\
\hline$\phi$ & degree & 40 & 20 & --- \\
\hline$\psi$ & degree & 0 & 0 & - \\
\hline
\end{tabular}

Properties of the Model. The finite element simulation was carried out with the aid of the PLAXIS2D code. The dimensions of the raft foundation are $23 \times 23 \mathrm{~m}$ with a thickness of $0.8 \mathrm{~m}$, and the dimensions of the overall model are $138 \times 138 \mathrm{~m}$ and the height $30 \mathrm{~m}$. It is taking the size of the model to ensure the necessary dimension that eliminates the effect of the boundary conditions. The location 
of the raft foundation is fixed in the middle of the model and on the surface of the earth, as shown in Figure 1a.

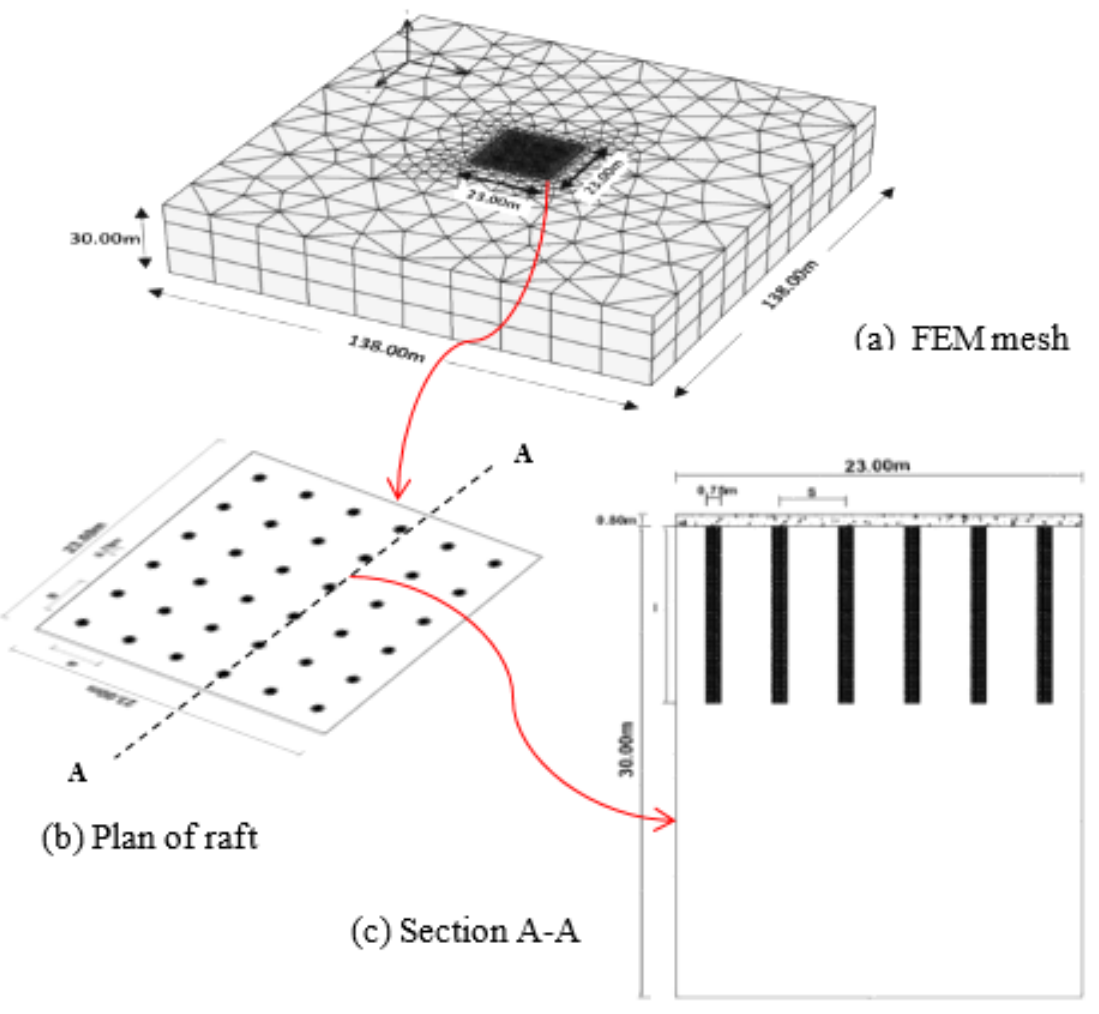

Figure 1. Numerical model.

Three types of stone column sections were used: the circular section with a diameter of $0.75 \mathrm{~m}$, the rectangular section with dimensions $0.5 \times 1.0 \mathrm{~m}$ with an area approximately equivalent to the circular section, and the square section with a side length of $0.665 \mathrm{~m}$ equivalent to the circular section. The spacing ( $\mathrm{s}$ ) between the stone columns was considered as the ratio of the spacing between the columns to their diameter $(\mathrm{s} / \mathrm{d})$. Different values were taken for the spacing between the stone columns equal in both directions with ratios ( $\mathrm{s} / \mathrm{d}=3,4$, and 5$)$ and the lengths of the piles $\mathrm{L} / \mathrm{d}=2,4$, 6,8 , and 10 as shown in Figure $1 \mathrm{~b}$ and $\mathrm{c}$. The spacing was $2.25,3.00$, and $3.75 \mathrm{~m}$, which represent the spacing of converging to divergent columns.

\section{Results and Discussion}

Circular Section. The effect of variant spacing between the stone columns taken as a ratio (s/d) on the attitude of weak soil with a circular cross-section has a diameter of $0.75 \mathrm{~m}$. The load-settlement relationship for various column lengths presented in Figure 2. The spacing effect is evident at loads exceeding $30 \mathrm{kN} / \mathrm{m}^{2}$, while the spacing between the stone columns does not significantly affect loads below that. This is because small loads do not generate a concentration of stresses in the stone columns, and the stress ratio in the stone columns to the soil is still close to one. At a normal load of $150 \mathrm{kN} / \mathrm{m}^{2}$, Figure 3 shows that the settlement value for a certain length ratio increases with an increase $(\mathrm{s} / \mathrm{d}$ ). Obviously, that the settlement decreases by $11.2 \%$ (from $251 \mathrm{~mm}$ to $223 \mathrm{~mm}$ ) when the value of $(\mathrm{s} / \mathrm{d})$ decreases from 5 to 3 for the long columns $(\mathrm{L} / \mathrm{d}=10)$, to be $7.4,7.5,8.0$, and $9.0 \%$, respectively for the column lengths $\mathrm{L} / \mathrm{d}=2,4,6$, and 8 . From the preceding, it can be seen that the rate of improvement in settlement owing to the spacing ratio $(\mathrm{s} / \mathrm{d})$ increases with increasing the length of the columns. It is noticed that the decrease in the settlement is almost at a constant rate with the decrease of the $(\mathrm{s} / \mathrm{d})$ value. This is due to an increase in soil confinement and providing more friction and stiff materials with a more area replacement ratio that all reduce settlement. Said et al. [18] found that the settlement of the soft soil decreased with the further area replacement ratio. 

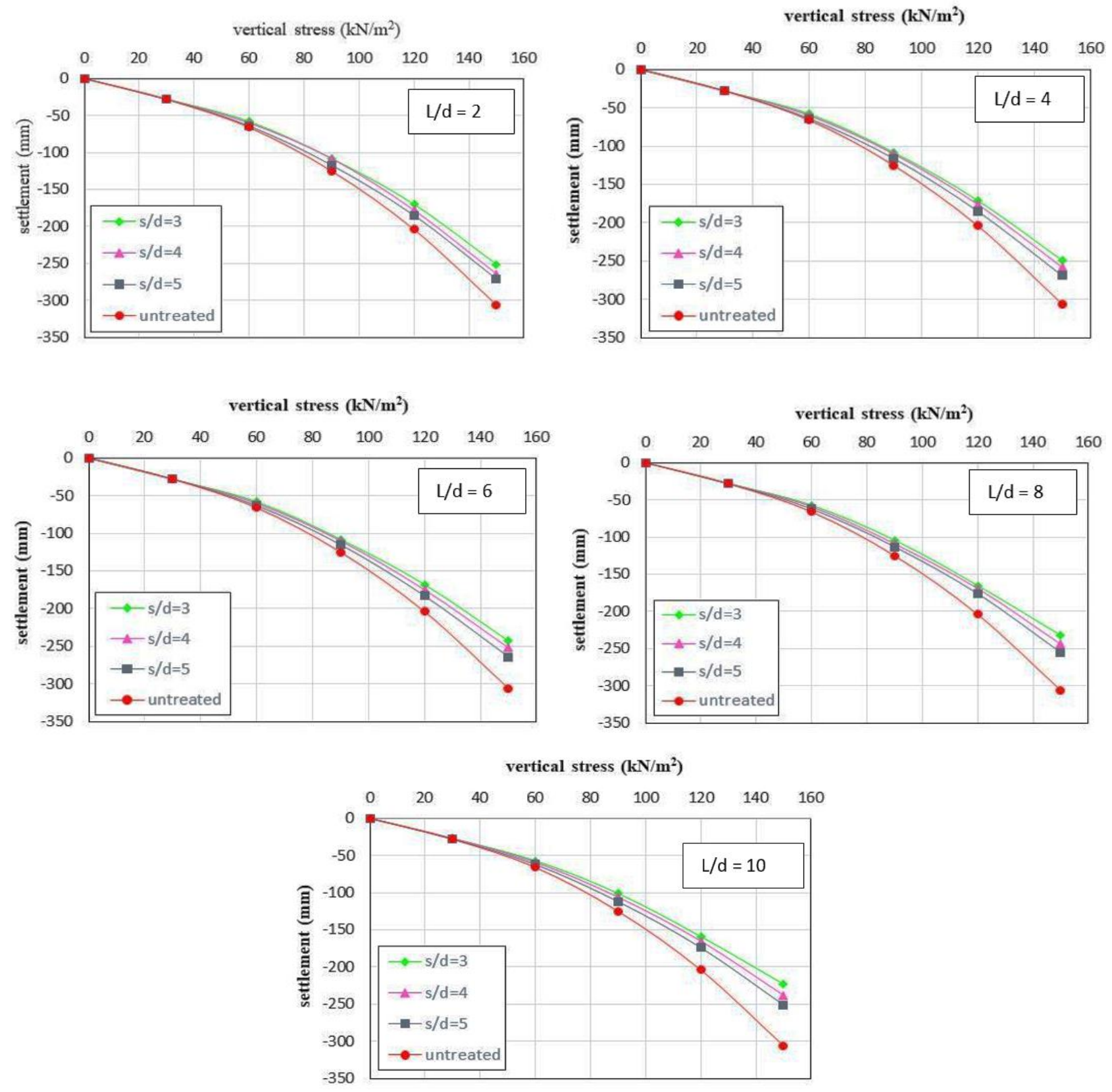

Figure 2. Load-settlement relationships of soil with stone columns of circular section.

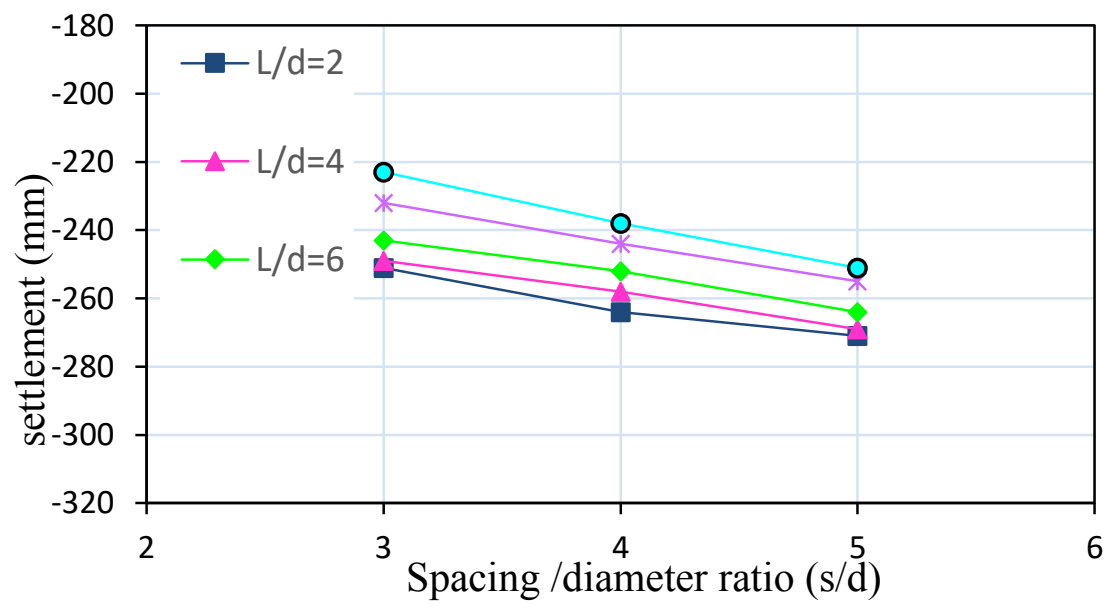

Figure 3. Variation of settlement with a spacing ratio of circular stone columns. 
Table 2 shows that the amount of soil bearing obtained at $100 \mathrm{~mm}$ settlement decreases with the increases of the columns' spacing ( $\mathrm{s} / \mathrm{d})$. The effect of spacing is greater with the larger column's length. This is due to an increase in the soil confinement and an increase in the concentration of stresses in the stone columns. With a short length of columns $(\mathrm{L} / \mathrm{d}=2)$, the improvement in the soil bearing is $10.2,8.7$, and $4.0 \%$ for spacing $(\mathrm{s} / \mathrm{d}=3,4$, and 5$)$, respectively, over untreated ones. The corresponding rate of improvement is $15.5,11.5$, and $7.1 \%$ with long columns $(\mathrm{L} / \mathrm{d}=10)$. The decrease in the spacing from $(\mathrm{s} / \mathrm{d}=5)$ to $(\mathrm{s} / \mathrm{d}=3)$ occupies an increase in the bearing capacity by $6.0 \%$ and $7.9 \%$ for $(\mathrm{L} / \mathrm{d}=2$ and 10$)$ respectively. This is due to the increase in the confinement and the area of the replacement ratio $[9,16]$. In general, it can be said that there is a relative improvement in the bearing capacity of the soil, coinciding with the establishment of columns in the soft soil. This results from the transfer of stresses to the stone columns as a result of the strength of the material composing the columns with respect to the low strength of the soft soil.

Table 2. The ultimate bearing capacity of soil with stone columns at $100 \mathrm{~mm}$ settlement subjected to the normal load of $150 \mathrm{kN} / \mathrm{m}^{2}$.

\begin{tabular}{|c|c|c|c|c|c|c|c|c|c|}
\hline \multirow{3}{*}{ L/d } & \multicolumn{9}{|c|}{$q_{\text {ult }}\left(\mathrm{kN} / \mathrm{m}^{2}\right)$} \\
\hline & \multicolumn{3}{|c|}{ Circular section } & \multicolumn{3}{|c|}{ Rectangular section } & \multicolumn{3}{|c|}{ Square section } \\
\hline & $\mathrm{s} / \mathrm{d}=\mathbf{3}$ & $\mathrm{s} / \mathrm{d}=4$ & $\mathrm{~s} / \mathrm{d}=5$ & $\mathrm{~s} / \mathrm{d}=3$ & $\mathrm{~s} / \mathrm{d}=4$ & $\mathrm{~s} / \mathrm{d}=5$ & $\mathrm{~s} / \mathrm{d}=\mathbf{3}$ & $\mathrm{s} / \mathrm{d}=4$ & $\mathrm{~s} / \mathrm{d}=5$ \\
\hline 0 & 77.3 & 77.3 & 77.3 & 77.3 & 77.3 & 77.3 & 77.3 & 77.3 & 77.3 \\
\hline 2 & 85.2 & 84.0 & 80.4 & 85.0 & 83.3 & 79.8 & 84.6 & 83.0 & 80.8 \\
\hline 4 & 85.2 & 84.0 & 80.8 & 85.1 & 84.4 & 80.8 & 84.6 & 83.9 & 80.9 \\
\hline 6 & 85.2 & 84.0 & 81.4 & 86.2 & 84.9 & 81.4 & 85.6 & 85.1 & 81.5 \\
\hline 8 & 87.5 & 84.6 & 82.4 & 88.0 & 85.0 & 81.8 & 88.0 & 85.1 & 83.3 \\
\hline 10 & 89.3 & 86.2 & 82.8 & 89.3 & 85.5 & 81.8 & 88.7 & 85.6 & 83.4 \\
\hline
\end{tabular}

Figure 4 typically illustrates the concentration and distribution of stress in a section taken in soil and stone columns. The stress concentration increases as the columns become close to each other. Gaber et al. [19] stated that the stress concentration ratio in stone columns decreased with increasing $(\mathrm{s} / \mathrm{d})$. This is interpreting the improvement in bearing capacity and drop in the settlement as the spacing between stone columns decreases.

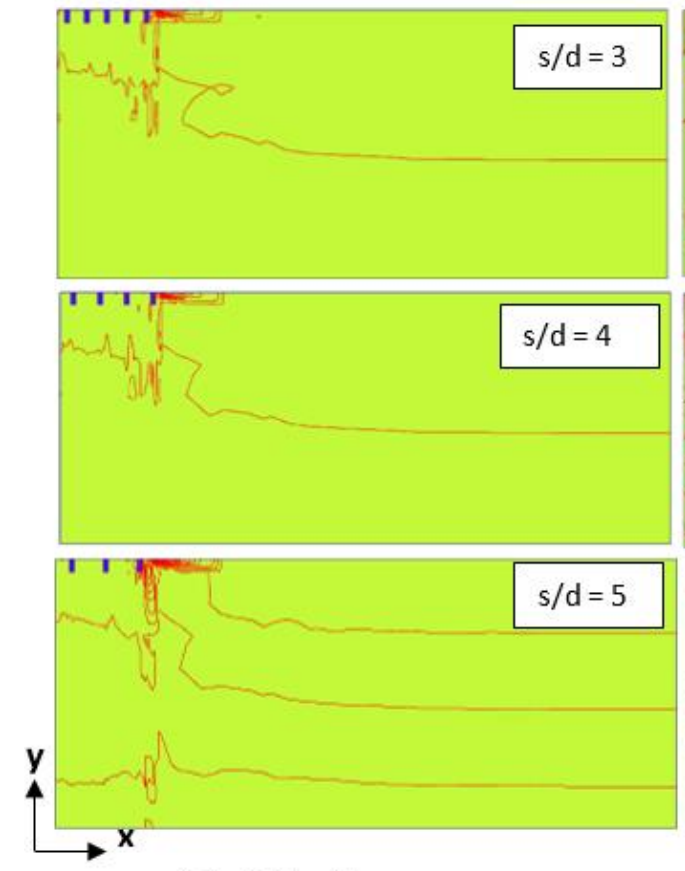

(a) $\mathrm{L} / \mathrm{d}=2$
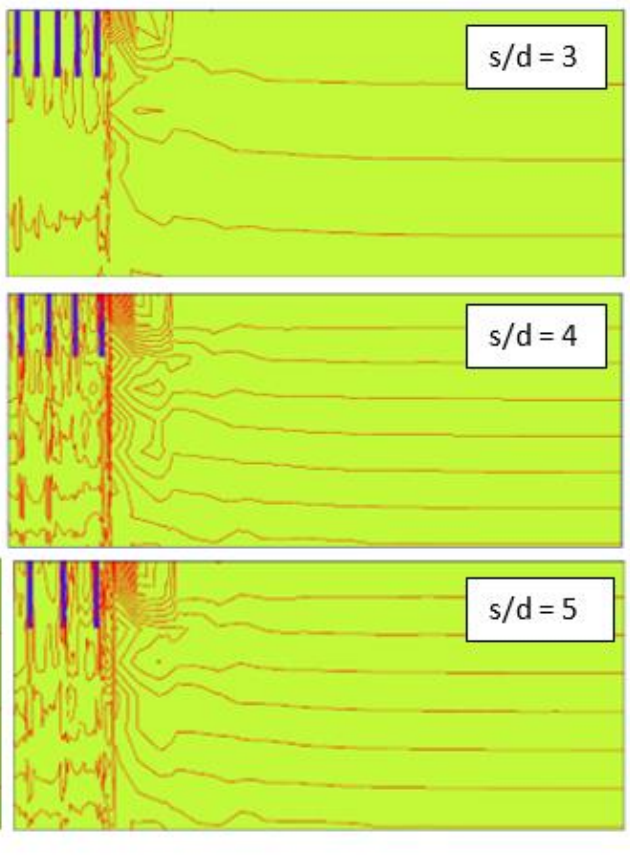

(b) $\mathrm{L} / \mathrm{d}=10$

Figure 4. Stress concentration in the treated soil with stone columns of circular section. 
Rectangular Section. Figure 5 shows the load-settlement relationship of the stone columns with a section of rectangular shape has dimensions of $1.0 \times 0.5 \mathrm{~m}$ which is approximately corresponding to the area of a circular section with a diameter of $0.75 \mathrm{~m}$, and for spacing between the columns with a ratio of $\left(\mathrm{s} / \mathrm{d}=3,4\right.$, and 5). The spacing affects the applied load of $30 \mathrm{kN} / \mathrm{m}^{2}$. At lower such load, there will be no effect of spacing on the settlement, which is identical to the stone columns of a circular section. From the load-settlement relationships, Figure 6 plotted, which shows the effect of changing the columns' spacing $(\mathrm{s} / \mathrm{d})$ on the settlement of the soil for various lengths of the stone columns $(\mathrm{L} / \mathrm{d})$ at a normal load of $150 \mathrm{kN} / \mathrm{m}^{2}$. A uniform decrease in a settlement with spacing for all columns length. The settlement at length ratios (L/d) of 2, 4, 6, 8, and 10 are 253, 248, 240, 228, and $220 \mathrm{~mm}$, respectively, for a distance of $(\mathrm{s} / \mathrm{d}=3)$ and $262,260,251,244$, and $236 \mathrm{~mm}$ for a distance of $(\mathrm{s} / \mathrm{d}=4)$ and $271,268,266,257$, and $251 \mathrm{~mm}$ in the case of $(\mathrm{s} / \mathrm{d}=5)$ under a normal load of $150 \mathrm{kN} / \mathrm{m}^{2}$. The results indicate that the settlement decreases by $12.4 \%$ with long columns $(\mathrm{L} / \mathrm{d}=10)$ due to the change of $(\mathrm{s} / \mathrm{d})$ from 5 to 3 . At the same time, a lower reduction of $6.6 \%$ was obtained with short columns $(\mathrm{L} / \mathrm{d}=2)$. The change spacing between columns of the rectangular section is more effective than that with the circular section.
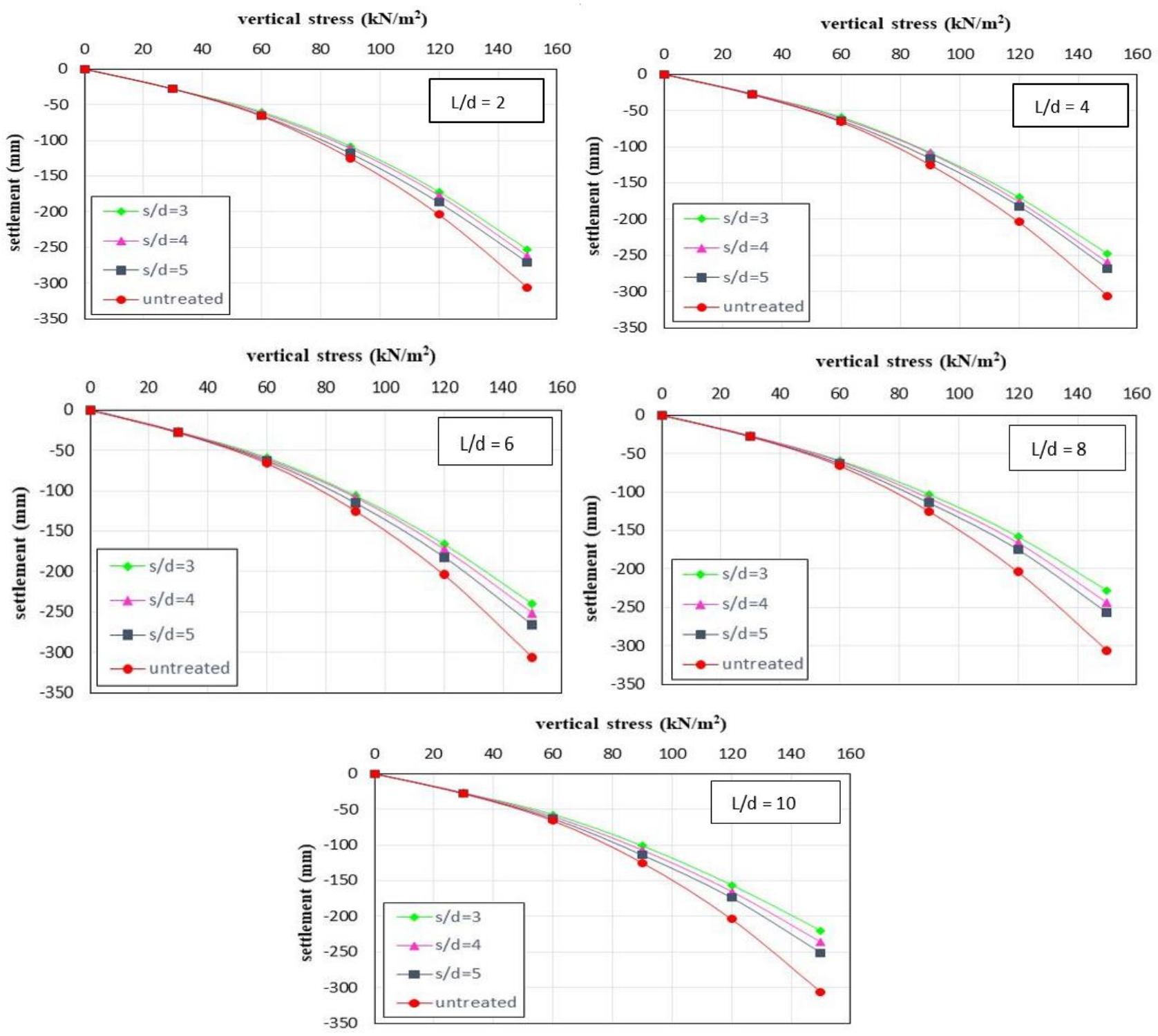

Figure 5. Load-settlement relationships of soil with stone columns of rectangular section. 


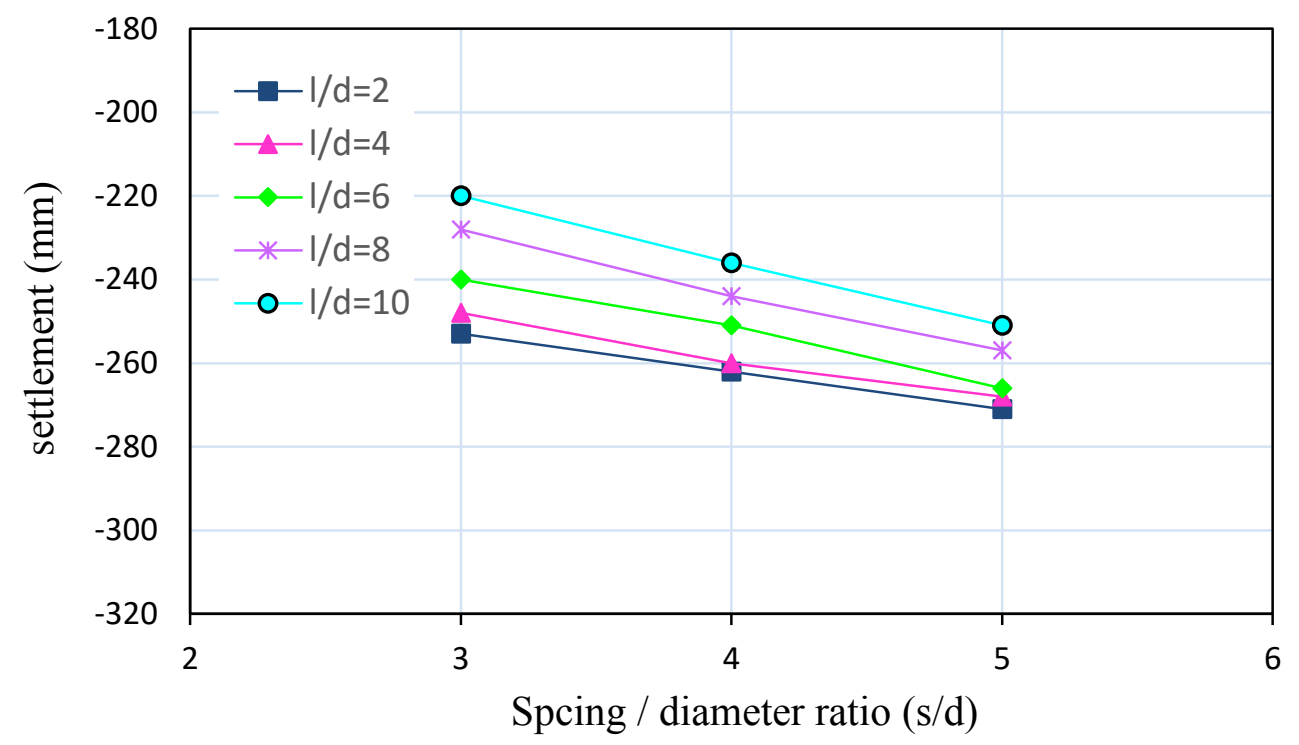

Figure 6. Variation of settlement with a spacing ratio of rectangular stone columns.

Table 2 shows the improvement in soil bearing that treated with stone columns of a rectangular cross-section. The stone columns of short length $(\mathrm{L} / \mathrm{d}=2)$ enhanced the soil bearing at $100 \mathrm{~mm}$ settlement by $10.0,7.8$, and $3.2 \%$ for spacing $(\mathrm{s} / \mathrm{d}=3,4$, and 5$)$, respectively untreated soil. These improvements become $15.5,10.6$, and $5.8 \%$ at $(\mathrm{L} / \mathrm{d}=10)$. It can be concluded that the amount of soil bearing in the case of short columns $(\mathrm{L} / \mathrm{d}=2)$ increases by $6.5 \%$ when the spacing ratio changes from $(\mathrm{s} / \mathrm{d}=5)$ to $(\mathrm{s} / \mathrm{d}=3)$, while it increases by $9.2 \%$ in the case of long columns $(\mathrm{L} / \mathrm{d}=10)$. The percentages of improvement are slightly higher than those obtained in the aforementioned circular section with the same behavior. As mentioned previously, the improvement in soil bearing capacity with decreased spacing is attributed to the increase of confinement and the increase in the area of the replacement ratio. A similar stress concentration pattern of the circular section (Figure 4) has been observed in the rectangular section. An increase in the concentration of stresses in the stone columns compared with the neighboring soil causes enhancement in the settlement and soil bearing.

Square Section. As for stone columns with a square section with a side length of $0.665 \mathrm{~m}$, which is a special case of columns with a rectangular section that corresponds to the area of the circular section of $0.75 \mathrm{~m}$ diameter. Figure 7 shows some improvement in soil settlement that treated with stone columns have a square section. The settlements at $(\mathrm{L} / \mathrm{d}=2)$ are 247,261 , and $271 \mathrm{~mm}$ for the treated soil with columns of spacing $(\mathrm{s} / \mathrm{d}=3,4$, and 5), respectively, compared to the untreated soil of $306 \mathrm{~mm}$. The decreases in spacing from $(\mathrm{s} / \mathrm{d}=5)$ to $(\mathrm{s} / \mathrm{d}=3)$ resulted in a reduction in settlement by $8.9 \%$ for short columns $(\mathrm{L} / \mathrm{d}=2)$ and by $11.5 \%$ for long columns $(\mathrm{L} / \mathrm{d}=10)$. It is noticed in Figure 8 that the maximum reduction in the settlement achieves at length ratio $(1 / \mathrm{d}=2)$ when treated soil with columns of a square section, similar to their equivalents in circular and rectangular sections. As the length of the column increases, occupied by a decrease in the settlement, but at a lower rate.

The amount of soil bearing obtained at the settlement of $100 \mathrm{~mm}$ increases with a decreased spacing comparable to columns of circular and rectangular sections, as shown in Table 2 . The short columns $(\mathrm{L} / \mathrm{d}=2)$ showed improvement in the bearing capacity of the soil by $9.4,7.4$, and $4.5 \%$ for spacing ratio $(\mathrm{s} / \mathrm{d}=3,4$, and 5$)$, respectively. The corresponding increases in the bearing capacity with long columns $(\mathrm{L} / \mathrm{d}=10)$ are $14.7,10.7$, and $7.9 \%$. Obviously, the bearing capacity slightly changes with the spacing. The increases in the soil bearing are $4.7 \%$ when the spacing decreased from $(\mathrm{s} / \mathrm{d}=5)$ to $(\mathrm{s} / \mathrm{d}=3)$ for $(\mathrm{L} / \mathrm{d}=2)$, and it increases by $6.4 \%$ for $(\mathrm{L} / \mathrm{d}=10)$ with corresponding spacing. The concentration of stress increases in the stone columns concerning the neighboring soil, similar to that shown in the circular section (Figure 4). As mentioned previously, the stress concentration affects the settlement as well as the soil bearing. 

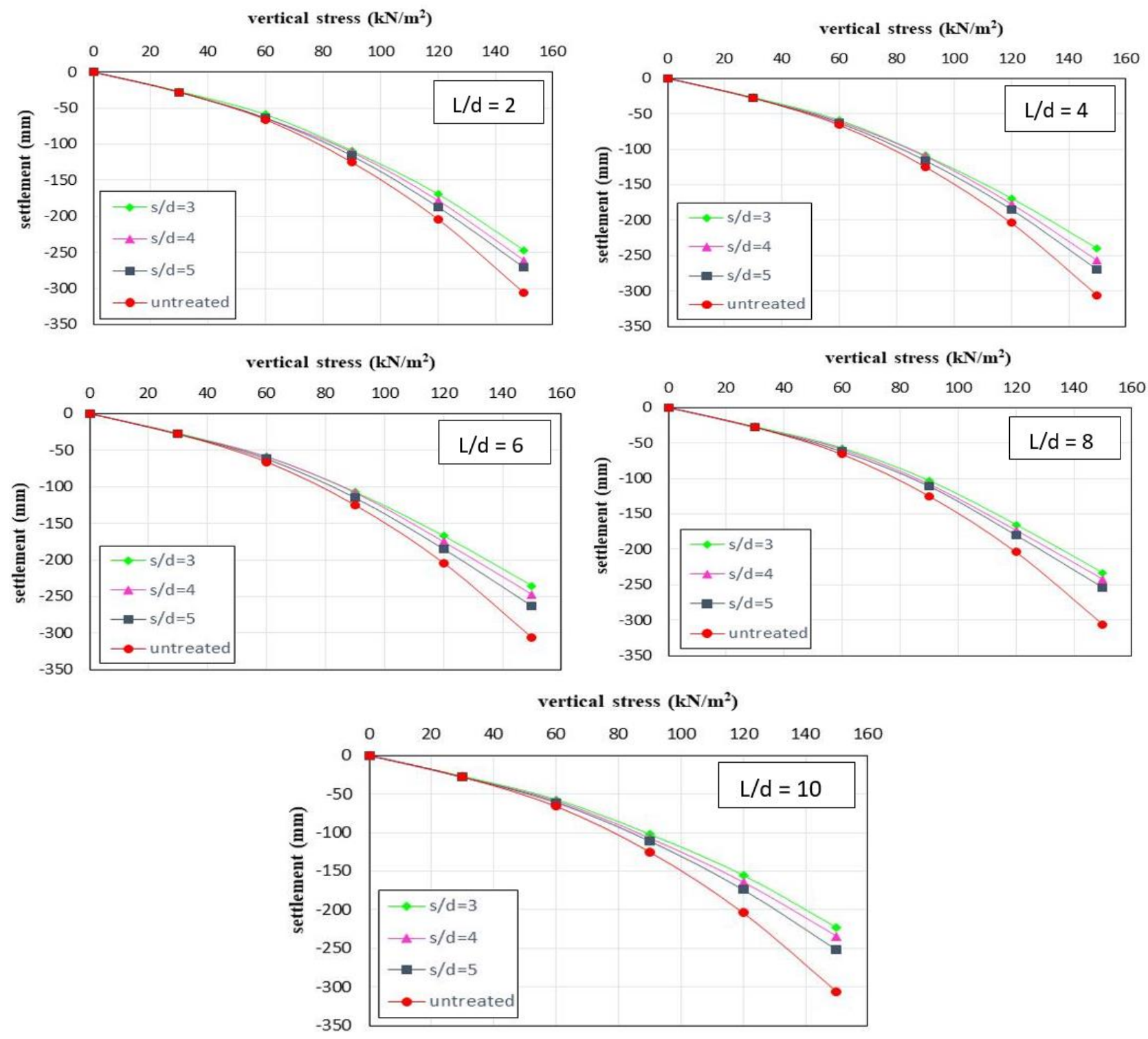

Figure 7. Load-settlement relationships of soil with stone columns of square section.

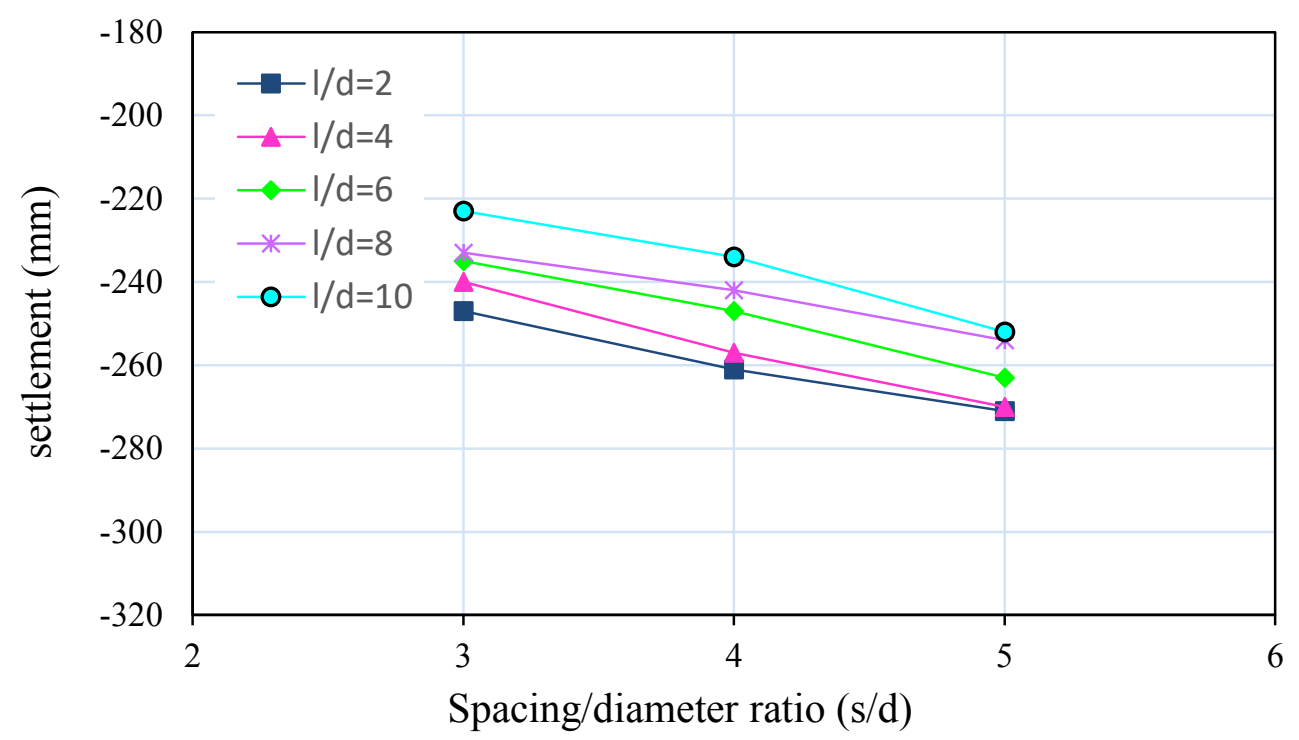

Figure 8. Variation of settlement with a spacing ratio of square stone columns. 


\section{Conclusions}

- The stone column's shape did not significantly affect the settlement and bearing capacity with the changing the spacing between the columns.

- The spacing between the columns clearly shows it is an effect at the vertical load of more than $30 \mathrm{kN} / \mathrm{m}^{2}$, and below this, there is no effect of the spacing.

- In general, the settlement decreases and bearing capacity increases when the spacing of stone columns decreases. The spacing becomes a more noticeable effect with the longer stone columns.

- The percentage of settlement improvements is $7.4,6.6$, and $8.9 \%$ for columns with circular, rectangular, and square sections, respectively, when the spacing decreases $(\mathrm{s} / \mathrm{d}=5)$ to $(\mathrm{s} / \mathrm{d}=3)$ at the columns' length of $\mathrm{L}=2 \mathrm{~d}$. The corresponding percentages of the settlement improvement are $11.2,12.4$, and $11.5 \%$ at columns' length of $(\mathrm{L} / \mathrm{d}=10)$.

- The bearing capacity of the soil increases with the decrease in the spacing between the stone columns, but with a slight change. For $(\mathrm{L} / \mathrm{d}=2)$, the changing the spacing ratio from $(\mathrm{s} / \mathrm{d}=5)$ to $(\mathrm{s} / \mathrm{d}=3)$, the improvements are $6.0,6.5$, and $4.7 \%$ for circular, rectangular and square sections respectively. Whereas the corresponding improvements are greater when increasing the length of the column to $(\mathrm{L} / \mathrm{d}=10)$ to be $7.9,9.2$, and $6.4 \%$. Regarding the bearing capacity, it is obvious that the spacing is more effective in rectangular sections.

- Based on the settlement results, the spacing between the stone columns is more effective in the case of short columns of a square section, while the rectangular section is better in the case of long columns. At the same time, the results of soil bearing show that the spacing is more effective in the case of the rectangular section.

\section{References}

[1] Wang, S., Chen, D. and Wang, R., 2011, July. Design of vibro-replacement stone column for foundation of multipurpose utility tunnels in Dalian. In 2011 Second International Conference on Mechanic Automation and Control Engineering (pp. 2070-2074). IEEE.

[2] Fattah, M.Y., Zabar, B.S. and Hassan, H.A., 2014. An experimental analysis of embankment on stone columns. Journal of Engineering, 20(7), pp.62-84.

[3] Killeen, M.M. and McCabe, B.A., 2014. Settlement performance of pad footings on soft clay supported by stone columns: a numerical study. Soils and Foundations, 54(4), pp.760-776.

[4] Bae, W.S., Shin, B.W., An, B.C. and Kim, J.S., 2002, January. Behaviors of foundation system improved with stone columns. In The Twelfth International Offshore and Polar Engineering Conference. International Society of Offshore and Polar Engineers.

[5] Black, J.A., Sivakumar, V. and Bell, A.L., 2010, June. Performance and observations of model stone column foundations. In Proceedings of the 7th International Conference on Physical Modelling in Geotechnics (ICPMG 2010) (pp. 1313-1318). CRC Press.

[6] Maheshwari, P. and Khatri, S., 2010. Nonlinear response of footings on granular bed-stone column-reinforced poor soil. International Journal of Geotechnical Engineering, 4(4), pp.435443.

[7] El-Garhy, B., Maraie, M. and Youssef, A.F., 2011. Behavior of model footings resting on soft clay reinforced by floating granular piles: experimental study. International Journal of Geotechnical Engineering, 5(4), pp.415-424.

[8] Eied, M.M., Helmy, H.M. and El-Kaissouny, M.G., 2014. Numerical Analysis of Ground Improvement by Group of Ordinary and Encased Stone Columns. Journal of American Science, 10(2).

[9] Fattah, M.Y., Zabar, B.S. and Hassan, H.A., 2016. Experimental analysis of embankment on ordinary and encased stone columns. International Journal of Geomechanics, 16(4), p.04015102.

[10] Fattah, M.Y., Al-Neami, M.A. and Al-Suhaily, A.S., 2017. Estimation of bearing capacity of floating group of stone columns. Engineering science and technology, an international journal, 20(3), pp.1166-1172. 
[11] Mokhberi, M. and Khademi, H., 2017. The Use of Stone Columns to Reduce the Settlement of Swelling Soil Using Numerical Modeling. Journal of civil Engineering and Materials Application, 1(2), pp.45-60.

[12] Al-Waily, M.J.M., Fattah, M.Y. and Al-Qaisi, M.S., 2020. Experimental and Statistical Study on Single and Groups of Stone Columns. In Key Engineering Materials (Vol. 857, pp. 399-408). Trans Tech Publications Ltd.

[13] Bonab, S.B., Lajevardi, S.H., Saba, H.R., Ghalandarzadeh, A. and Mirhosseini, S.M., 2020. Experimental studies on single reinforced stone columns with various positions of geotextile. Innovative Infrastructure Solutions, 5(3), pp.1-12.

[14] Bouziane, A., Jamin, F., El Mandour, A., El Omari, M., Boussassida, M., and El Youssoufi, M.S., 2020. Experimental study on a sealed test model soil reinforced by stone columns. European Journal of Environmental and Civil Engineering (2020). https://doi.org/10. 1080/19648189.2020.1716852

[15] Nav, M.A., Rahnavard, R., Noorzad, A. and Napolitano, R., 2020, June. Numerical evaluation of the behavior of ordinary and reinforced stone columns. In Structures (Vol. 25, pp. 481-490). Elsevier.

[16] Thakur, A., Rawat, S. and Gupta, A.K., 2021. Experimental and numerical modelling of group of geosynthetic-encased stone columns. Innovative Infrastructure Solutions, 6(1), pp.1-17.

[17] Al-Obaydi, M.A. and Al-Kazzaz, Z.A., 2020. Analytical Study of Load-Settlement Behavior of Soil Treated with Stone Columns have Different Sectional Shape. In Key Engineering Materials (Vol. 857, pp. 319-327). Trans Tech Publications Ltd.

[18] Nissa Mat Said, K., Safuan A Rashid, A., Osouli, A., Latifi, N., Zurairahetty Mohd Yunus, N. and Adekunle Ganiyu, A., 2019. Settlement evaluation of soft soil improved by floating soil cement column. International Journal of Geomechanics, 19(1), p.04018183.

[19] Gaber, M., Kasa, A., Rahman, N.A. and Alsharef, J.M., 2018. Comparison between unit cell and plane strain models of stone column ground improvement. International Journal of Engineering \& Technology, 7(2), pp.263-269. 